Insignia Journal of International Relations

Vol. 6, No.2, November 2019, 94-105

P-ISSN: 2089-1962; E-ISSN: 2597-9868

\title{
Alasan Pembentukan Kerja Sama Keamanan ASEAN-Australia dalam Menghadapi Isu Terorisme
}

\author{
Ervina Fredayani \\ Jurusan Hubungan Internasional, Universitas Muhammadiyah Malang \\ Email: ervinafredayani7@gmail.com \\ Jordan Aria Adibrata \\ Jurusan Hubungan Internasional, Universitas Muhammadiyah Malang \\ Email: jordanaria2@gmail.com \\ Naufal Fikhri Khairi \\ Jurusan Hubungan Internasional, Univesitas Muhammadiyah Malang \\ Email: naufalfikhri1999@gmail.com
}

\begin{abstract}
Abstrak
Saat ini isu terorisme di Kawasan Asia Tenggara menjadi hal yang cukup penting untuk diperbincangkan, kawasan ini menjadi wilayah yang berpotensi besar akan hadirnya tindak kekerasan terorisme. Kehadiran kelompok islam radikal di Asia Tenggara menjadi faktor utama maraknya ancaman teror yang belakangan ini dirasa cukup meresahkan dan menimbulkan ketakutan terhadap masyarakat sekitar. Adanya hal ini kemudian membuat negara - negara di Kawasan Asia Tenggara bersepakat untuk mengantisipasi penyebaran aksi terorisme dengan menjalin kerja sama dengan Australia. Adapun penelitian ini bertujuan untuk mengetahui alasan kerja sama keamanan yang dilakukan oleh ASEAN dengan Australia dalam menghadapi ancaman terorisme, khususnya di Kawasan Asia Tenggara. Penggunaan Konsep Kerja Sama Keamanan Internasional dan Konsep Motivasi Kerja Sama Internasional sebagai alat dalam menjelaskan fenomena yang dikaji. Pada penelitian ini penulis menggunakan metode penelitian kualitatif dengan teknik pengumpulan data, telaah pustaka, buku, artikel, jurnal, dan dokumen - dokumen lainnya untuk dapat menganalisa permasalahan tersebut. Hasil dari penelitian ini menunjukkan bahwa terdapat beberapa alasan kerja sama keamanan yang dijalin oleh ASEAN dan Australia, meliputi menjaga keamanan nasional dan perdamaian kawasan dari adanya aksi-aksi teror yang melibatkan organisasi-organisasi terorisme. Walaupun masih belum mencapai hasil yang diinginkan, kerja sama yang dijalin oleh ASEAN dan Australia ini diharapkan dapat semakin meningkatkan keamanan regional dari kedua belah pihak.
\end{abstract}

Kata Kunci: ASEAN, Australia, Kerja Sama Terorisme

\begin{abstract}
At this time the problem of terrorism in the Southeast Asian Region is quite important to discuss, this region is a region with great potential for the presence of acts of terrorism. The presence of radical Islamic groups in Southeast Asia has become a major factor in the emergence of terror threats, which lately is considered quite disturbing and frightening to surrounding communities. This existence then made the countries in the Southeast Asia Region agree to anticipate the spread of terrorist acts by establishing cooperation with Australia. This study aims to determine the reasons for security cooperation undertaken by ASEAN and Australia in dealing with the threat of terrorism, particularly in the Southeast Asian Region. The use of the Concept of International Security Cooperation and the Concept of Motivation for International Cooperation as tools in explaining the phenomenon under study. In this study the authors used qualitative research methods with data collection techniques, literature reviews, books, articles, journals, and other documents to be able to analyze the problem. The results of this study reveal several reasons for the security cooperation established by ASEAN and Australia, including national security and regional peace from acts of terror involving terrorist organizations. Although it has not yet achieved the desired results, the cooperation carried out by ASEAN and Australia is expected to increase regional security from both parties.
\end{abstract}

Keyword: ASEAN, Australia, Terrorism Cooperation 


\section{PENDAHULUAN}

Belakangan ini muncul beberapa isuisu baru yang sebelumnya tidak ada pada masa Perang Dunia I hingga Perang Dingin. Isu baru ini muncul setelah Perang Dingin berakhir, dimana hal ini membuat dunia berubah. Adapun isu-isu baru tersebut adalah konflik etnis, terorisme internasional, benturan peradaban, dan segala bentuk aspek dari adanya globalisasi (Rizka, 2016). Munculnya isu-isu ini membawa perubahan pada seluruh dunia termasuk dalam interaksi global (Perwita \& Yani, 2005). Isu yang memberikan tantangan besar saat ini adalah isu terorisme, dimana terorisme menjadi isu atau permasalahan lintas batas negara atau transnasional. Ancaman terorisme ini muncul sejak peristiwa 9/11, yaitu proses penyerangan gedung World Trade Centre (WTC) dan Pentagon di Amerika Serikat. Kemudian peristiwa ini oleh Presiden Amerika Serikat (AS) George W. Bush dideklarasikan sebagai war on terrorism secara global (Suwardi, 2002). Mulai saat itu, negara-negara di seluruh dunia bersama-sama memerangi ancaman tindak kekerasan atau terorisme internasional.

Peristiwa 9/11 menyebabkan negaranegara di seluruh dunia mulai membuat strategi untuk meningkatkan keamanan, baik dalam skala nasional maupun internasional. Keamanan yang dilakukan oleh negara-negara ini tidak hanya melalui peningkatan keamanan militer atau hard power melainkan juga dengan cara soft power yakni melalui teknologi. Strategi soft power atau melalui teknologi ini dilakukan karena menyesuakian dengan adanya perkembangan teknologi saat ini. Tindak kejahatan terorisme ini juga melakukan aksinya melalui teknologi atau sering kali disebut dengan istilah kejahatan siber (cybercrime), sehingga keamanan soft power atau melalui teknologi perlu untuk dilakukan (Rizka, 2016). Maka dari itu, hal ini harus dihadapi dengan cara bersamasama agar ruang gerak terorisme menjadi sempit (Rizka, 2016).
Saat ini kawasan Asia Tenggara menjadi wilayah yang berpotensi mendapatkan ancaman terorisme lebih besar. Hal ini disebabkan oleh adanya berbagai kelompok Islam radikal yang bergerak ke arah terorisme. Kelompok islam radikal ini seperti Jemaah Islamiyah (JI) di Indonesia, Moro Islamic Liberation Front (MILF), Abu Sayyaf Group (ASG), dan Bangsamoro Islamic Freedoms Fighter (BIFF) di Filipina (Chandran, 2015). Kelompok Abu Sayyaf dan JI dianggap sebagai organisasi teroris yang paling berbahaya di dunia (Tempo, 2015).

Dari beberapa kelompok teroris di atas, kelompok teroris yang ada di Indonesia banyak sekali mendapatkan aliran dana dari mancanegara seperti Malaysia, Australia dan beberapa negara-negara yang berasal dari Timur Tengah (Deutsche Welle, 2016). Negara Australia saat ini menjadi negara paling banyak memberikan aliran dana kepada teroris Indonesia melalui cara pernikahan (Deutsche Welle, 2016). Banyak warga Negara Australia yang menjadi teroris yang kemudian menikahi wanita Indonesia dan secara bersama keduanya melakukan aksi teror di Indonesia dan bersama membuat rekening untuk memberikan dana kepada jaringan teroris mereka (Deutsche Welle, 2016).

Peristiwa ini tidak hanya dilakukan oleh pihak Australia melainkan juga dilakukan oleh Indonesia ke manca negara seperti Hongkong (Deutsche Welle, 2016). Para teroris Indonesia juga melakukan pengucuran dana kepada para pelaku teror yang ada di Australia, Hongkong, Filipina dan lain sebagainya (Deutsche Welle, 2016). Aliran dana yang diberikan dari Indonesia untuk beberapa negara-negara biasanya dilakukan dengan menggunakan global payment gateaway seperti paypal dan instrumen virtual currency seperti bitcoin. Hal ini telah terbukti dari laporan yang diberikan oleh Pusat Pelaporan dan Analisis Transaksi Keuangan (PPATK) dimana badan ini telah memeriksa berbagai aliran dana 
yang masuk dan keluar di Indonesia (Deutsche Welle, 2016).

Persoalan tersebut membuat negaranegara anggota ASEAN menyadari bahwa mereka harus bergabung membentuk aliansi untuk bisa memerangi aksi terorisme yang mungkin akan mengancam wilayah ASEAN. Pemerintah masing-masing negara anggota ASEAN juga mulai menetapkan kebijakan terkait dengan perlawanan terhadap terorisme. Hal itu sesuai dengan penerapan salah satu pilar dari ASEAN Community dalam konteks membangun ASEAN Political Security Community (Rizka, 2016). Untuk mewujudkan pilar tersebut ASEAN bersama dengan Australia menjalin kerja sama untuk menghadapi terorisme yang menjadi isu utama di kawasan ASEAN (ASEAN, 2018).

Berdasarkan latar belakang tersebut peneliti mengamati bahwa kondisi di kawasan Asia Tenggara dan Australia saat ini memerlukan perhatian lebih terkait masalah keamanan. Selain itu perubahan alur kerja sama yang awalnya dari ekonomi kemudian beralih ke masalah keamanan juga menjadi hal yang penting untuk diketahui. Dari adanya hal itu, penulis mengajukan rumusan masalah mengenai mengapa negara-negara ASEAN dan Australia memperluas kerja sama dalam bidang keamanan. Menurut penulis, rumusan masalah tersebut menjadi hal yang menarik untuk dikaji karena sebelumnya kerja sama antara ASEAN dan Australia sejak awal hanya sebatas permasalahan perekonomian, namun beberapa tahun belakangan ini kerja sama dalam bidang keamanan semakin diperkuat.

\section{Kerangka Konseptual: Kerja Sama Keamanan Internasional}

Kerja sama merupakan istilah dalam ilmu hubungan internasional yang sering disebut dengan kerja sama internasional (Rizka, 2016). Kerja sama ini awalnya muncul dari adanya interaski sosial antarindividu. Kerja sama bisa dilakukan oleh dua negara atau lebih. Tujuan dari pembentukan suatu kerja sama antarnegara adalah mencapai kepentingan nasional suatu negara menjadi lebih mudah (Rizka, 2016). Kerja sama yang dilakukan oleh dua pihak ini disebut dengan istilah hubungan bilateral. Selain itu, adanya kerja sama ini terbentuk karena munculnya rasa saling ketergantungan satu sama lain dalam memenuhi kebutuhannya (Jackson \& Sorensen, 2009). Hal ini sama halnya dengan yang terjadi antara ASEAN dan Australia. Kedua pihak memutuskan untuk menjalin kerja sama guna mencapai kepentingan nasional masing -masing.

Kerja sama internasional dapat terbentuk karena kehidupan internasional meliputi berbagai bidang, seperti ideologi, politik, ekonomi, sosial, lingkungan hidup, kebudayaan, pertahanan, dan keamanan (Rizka, 2016). Hal-hal inilah yang memunculkan berbagai perbedaan kepentingan antara satu negara dengan negara lainnya. Oleh sebab itu, untuk bisa membuatnya lebih mudah maka perlu dibentuk suatu kerja sama antara beberapa negara agar kepentingan tersebut dapat tercapai berdasarkan pada keuntungan yang didapatkan oleh masing-masing pihak (Rizka, 2016). Kerja sama keamanan ini akan menjadi isu utama yang penting untuk diperhatikan bagi setiap negara karena keamanan menjadi hal fundamental bagi seluruh negara.

Kerja sama yang dijalin antara ASEAN dengan Australia dalam menghadapi terorisme merupakan sebuah upaya kedua pihak untuk bisa mencapai kepentingan masing-masing yakni menjaga keamanan wilayahnya dari ancaman terorisme yang saat ini telah menyebar semakin luas. Kerja sama keamanan ini dilakukan untuk menciptakan keamanan di lintas batas Kawasan Asia Tenggara dan Australia (ASEAN, 2018). Keamanan menjadi hal fundamental bagi setiap negara. PascaPerang Dingin berakhir, berbagai konflik atau permasalahan muncul tidak hanya dalam aspek ideologi seperti yang dilakukan antara Amerika Serikat dengan Uni Soviet, tetapi menjadi lebih kompleks. 
Permasalahan tersebut mulai dari aspek ekonomi, sosial budaya, keamanan, terorisme, politik, lingkungan dan lain sebagainya. Saat ini, isu terorisme menjadi hal yang perlu untuk diperhatikan oleh Kawasan Asia Tenggara. Sebab isu terorisme di Asia Tenggara saat ini begitu mengkhawatirkan dikarenakan banyaknya kelompok-kelompok radikal yang mulai bermunculan (Chandran, 2015). Oleh karena itu, ASEAN bersama dengan Australia berupaya untuk membuat strategi agar kepentingan nasional mereka dalam menjaga keamanan dan perdamaian dalam wilayah mereka dapat tercapai.

Keamanan sendiri, menurut Barry Buzan, menjadi hal fundamental bagi suatu negara sebab keamanan merupakan bentuk dari kebebasan suatu negara dari adanya ancaman dari luar dan kemampuan dari suatu negara maupun masyarakat dalam menjaga atau melindungi identitas kemerdekaan (Maulidy, 2011). Dasar utama dari keamanan yaitu bertahan hidup, yang dapat mencakup tradisi dan eksistensi suatu negara (Maulidy, 2011). Sedangkan keamanan regional itu sendiri, Berry Buzan mengungkapkan bahwa unsur-unsur yang ada dalam negara, pada prinsipnya ditambahkan dalam hubungan antar negara yang mana hal tersebut menjadi bagian dari integrasi antar negara (Maulidy, 2011).

Menurut Anak Agung Bayu Perwira dan Yahyan Mochammad Yani (2005), pada awalnya konsep dari keamanan ini bersifat tradisional. Namun, saat ini, sifat tersebut telah bergeser kearah non-tradisional. Adapun konsep keamanan memiliki beberapa dimensi. Pertama, the origin of threats, yang mana pada masa Perang Dingin ancaman yang muncul sebagian besar berasal dari luar atau faktor eksternal, akan tetapi di masa sekarang ancaman yang datang tidak hanya dari luar melainkan dari dalam atau domestik. Dengan demikian, ancaman yang berasal dari dalam dapat berupa ancaman isu budaya, agama, dan ras. Kedua, the nature of threats. Pada aspek tradisional, ancaman ini berfokus pada aspek atau dimensi militer sebagai bentuk dari ancaman yang diberikan. Akan tetapi, sesuai dengan perkembangan zaman ketika berbagai isu maupun ancaman juga semakin kompleks, ancaman yang muncul menjadi semakin sulit untuk dihadapi. Sebab hal ini mulai menyangkut aspek-aspek seperti ekonomi, politik, sosial, dan budaya.

Ketiga, changing response. Pada konteks ini, respon yang diberikan di masa lampau adalah dengan sebuah tindakan yang bersifat kekerasan atau tindakan militeris, sementara untuk saat ini, dengan isu-isu baru seperti permasalahan lingkungan, HAM, dan terorisme, perlu dihadapi dengan tindakan non-militer seperti halnya melalui ekonomi, politik, sosial, dan budaya. Keempat, changing responsibility of security. Para penganut konsep keamanan lama beranggapan bahwa negara masih menjadi sebuah organisasi politik yang memiliki tanggungjawab besar terhadap keamanan masyarakat atau individu di negaranya. Sementara itu, para penganut konsep keamanan "baru" menyatakan bahwas keamanan dari setiap individu akan lebih tinggi tergantung dari interaksi antarindividu di tataran global. Kelima, core value of security. Kelompok modernis berbeda dengan kelompok tradisionalis yang begitu mengedepankan keamanan pada national independence, kedaulatan, dan integrasi teritorial. Kelompok modernis lebih mengedepankan nilai-nilai baru, baik pada tataran individu maupun global, yaitu dengan nilai-nilai penghormatan pada HAM, demokratisasi, perlindungan terhadap lingkungan hidup, serta mengurangi kejahatan-kejahatan lintas batas.

Dari berbagai dimensi yang telah dipaparkan di atas, isu keamanan dalam hubungan internasional merupakan isu yang semakin kompleks, sehingga perlu adanya kerja sama yang dijalin antara satu negara dan negara lainnya dengan tujuan untuk menghadapi perkembangan isu yang ada. Maka dari itu, kerja sama yang dilakukan oleh ASEAN dan Australia sudah dianggap tepat dalam menghadapi isu terorisme yang 
belakangan ini marak terjadi di kawasan Asia Tenggara. Selain itu, keamanan di kawasan juga penting dilakukan dalam bentuk kerja sama agar negara-negara di kawasan dapat menghindari berbagai dampak negatif yang kemungkinan akan terjadi ke depan.

Selain itu, terdapat beberapa motivasi dari suatu negara yang bersedia untuk melakukan kerja sama menurut Peter Toma dan Robert Gorman (Rizka, 2016). Pertama, motivasi untuk memperkuat kepentingan nasional, yang mana kerja sama digunakan oleh negara sebagai alat untuk mencapai kepentingan nasionalnya. Kedua, motivasi untuk memelihara perdamaian. Kerja sama dilakukan dengan harapan dapat menghindari adanya sebuah konflik yang terjadi antar negara. Ketiga, motivasi untuk mendorong kemakmuran ekonomi. Suatu kerja sama diharapkan dapat meningkatkan kemakmuran ekonomi setiap Negara. Keempat, motivasi untuk menangani eksternalitas kerja sama yang diharapkan mampu menghilangkan dampak negatif yang ditimbulkan oleh manusia, seperti halnya terorisme.

Berdasarkan dari motivasi di atas, kerja sama ASEAN dengan Australia adalah kerja sama dalam menangani eksternalitas yakni terorisme khususnya di Kawasan Asia Tenggara. Tindakan terorisme merupakan upaya-upaya untuk meraih tujuan politik dengan menggunakan kekerasan untuk menciptakan iklim, ketakutan, dan ketidakpastian (Heywood, 2017). Tindakan atau aksi terorisme ini akan memberikan dampak negatif yang cukup besar bagi kawasan Asia Tenggara apabila tidak segera ditanggulangi. Oleh sebab itu, upaya dari negara-negara di kawasan Asia Tenggara ini melakukan kerja sama untuk menghadapi adanya ancaman terorisme. Meskipun demikian, kerja sama ASEAN dan Australia ini tidak hanya pada penanganan permasalahan ekternalitas, melainkan juga pada beberapa motivasi lainnya.

Adapun upaya dari ASEAN sendiri dalam menangani eksternalitas terorisme yaitu dengan membangun perjanjian antara negara-negara ASEAN, membagi normanorma dalam meningkatkan perjanjian gotong royong yang legal antara satu sama lain, membentuk kelompok kerja $A S E A N$ Extradition Treaty, menyusun ASEAN Convention on Counter Terrorism. Selain upaya tersebut, terdapat strategi yang digunakan untuk mengatasi permasalahan tindak kejahatan terorisme, yakni memerangi segala tindak kejahatan terorisme baik nasional maupun lintas batas, dan masalah-masalah lintas batas lainnya melalui aktivitas kerja sama regional (Hartanto, 2016). Keberhasilan ASEAN dalam menangani isu terorisme ini dengan menyelenggarakan ASEAN Defense Ministers Meeting (ADMM) pada tahun 2006, dan menghasilkan ASEAN Convention on Counter Terrorism (ACCT) yang menyediakan berbagai dasar hukum dalam menanggulangi terorisme (Hartanto, 2016).

Sedangkan ekternalitas yang dilakukan Australia dalam menghadapi ini yaitu dengan menegakkan badan khusus untuk menangani isu terorisme dari segi finansial. Badan hukum ini dinamakan The Australian Transaction and Reports Analysis Centre (ATRAC). Cara kerja badan ini yaitu dengan memonitor setiap transaksi yang dilakukan oleh bank. Selain itu, Australia juga membuat strategi dengan cara bekerja sama dengan komunitas untuk melawan propaganda ekstrimis yang penuh dengan kekerasan, membentuk lingkungan global untuk secara bersama melawan aksi terorisme dengan mengikuti tindakan internasional yang terkoordinasi untuk membuat lingkungan tidak kondusif bagi para teroris (Australia Government, 2015). Dalam hal ini, Australia juga menjalin berbagai kerja sama dengan mitranya dalam melawan terorisme, termasuk juga melalui Perserikatan BangsaBangsa (PBB).

\section{Metode Penelitian}

Pada penelitian ini penulis menggunakan jenis penelitian dengan pendekatan deskriptif kualitatif. Penelitian 
kualitatif merupakan tradisi tertentu dalam ilmu pengetahuan sosial yang secara fundamental bergantung pada pengamatan manusia dan berhubungan dengan orangorang tersebut dalam memberikan sebuah peristilahannya sendiri (Ansari, 2009). Penulis menggunakan teknik pengumpulan data studi dokumentasi berupa jurnal, artikel ilmiah, working paper, e-book, buku, dan berita online yang berkaitan dengan penelitian serta permasalahan yang peneliti tulis. Selain itu, untuk membantu menjawab permasalahan yang ingin penulis ketahui, yakni strategi kerja sama keamanan antara ASEAN dan Australia, penulis menggunakan kerangka analisis berupa konsep sekuritisasi dan kerja sama keamanan. Kerja sama keamanan menjadi sebuah hal penting dalam studi hubungan internasional saat ini, karena mulai adanya permasalahan yang semakin kompleks. Selain itu, keamanan menjadi entitas penting bagi setiap negara sehingga harus diutamakan.

\section{HASIL DAN PEMBAHASAN Pembentukan Kerja Sama Keamanan ASEAN-Australia}

Kerja sama ASEAN dalam menghadapi terorisme telah dilakukan sejak tahun 2001. Pada saat itu diadakan pertemuan Konferensi Tingkat Tinggi (KTT) ASEAN ke7 di Brunei Darrusalam (ASEAN, 2018). Pada KTT ke-7 tersebut menghasilkan ASEAN Declaration on Joint Action to Counter Terrorism, yang kemudian dilanjutkan dengan diadakannya KTT ke-8 di Phnom Phen, Kamboja pada bulan November tahun 2002 (ASEAN, 2018). Pada pertemuan tersebut menghasilkan mekanisme kerja sama pemberantasan terorisme yang dilakukan melalui AMMTC (ASEAN Ministerial Meeting on Transnasional Crime) dan SOMTC (Senior Official Meeting on Transnasional Crime), dimana Indonesia dipercaya menjadi lead shepherd di bidang counter terrorism sekaligus menjadi ketua Working Group on Counter Terrorism (WGCT) (ASEAN, 2018).
Kerja sama keamanan yang dilakukan oleh ASEAN dalam menghadapi terorisme saat ini semakin luas. ASEAN mulai meningkatkan kerja sama dengan mitra wicaranya seperti Australia. Kerja sama ASEAN dengan Australia dalam menghadapi terorisme ini dimulai setelah adanya $M o U$ (Memorandum of Understanding), dan secara resmi keduanya menjadi mitra strategis dalam bidang keamanan tahun 2014 (ASEAN, 2018). Kerja sama ASEAN-Australia pada awalnya diadakan karena pada saat ini mulai bermunculan isu-isu baru yang mengglobal seperti terorisme. Salah satu contoh yang menjadi perhatian adalah peristiwa Bom Bali 2 pada tahun 2004 yang mengakibatkan banyak korban asing dari Australia (Simanjuntak, 2016). Semenjak terjadinya peristiwa Bom Bali 2 yang membawa dampak negatif terhadap warga asing Australia, menjadikan Australia lebih waspada terhadap hadirnya ancaman teror di Australia sendiri. Sebab, setelah terjadinya aksi-aksi teror yang terjadi di Indonesia dan berakibat pada Australia, mulai bermunculan tindakan terorisme di negara Australia. Seperti belakangan ini di Australia banyak sekali tindakan teror yang terjadi, yakni mulai dari penikaman tiga pejalan kaki pasca-peledakan mobil di Melbourne, penusukan pejalan kaki di Jalan Swansen oleh salah seorang yang berasal dari Somalia, dan penyanderaan dua orang di Sydney hingga tewas (BBC, 2014).

Beberapa peristiwa di atas menunjukkan bahwa aksi terorisme mulai merambah ke wilayah Australia dengan cepat, dan hal ini dianggap akan sangat mengganggu keamanan nasional Australia sebab tindak kejahatan terorisme ini sangat sulit untuk diungkap pelakunya. Selain itu, semakin banyaknya pencari suaka yang masuk ke Australia dan sebagian besar berasal dari negara-negara Timur Tengah semakin membuat keamanan nasional Australia lebih terancam (BBC, 2016). Hal tersebut muncul karena adanya persepsi yang banyak muncul dari negara di seluruh dunia bahwa para pelaku teror banyak 
berasal dari negara-negara Timur Tengah yang mayoritas penduduknya beragama slam.

Bentuk ancaman teror yang diberikan oleh para teroris ini tidak hanya dalam bentuk secara fisik, tetapi juga dilakukan melalui berbagai teknologi yang ada (Mardiastuti, 2018). Hal ini semakin membuat Australia semakin khawatir, sebab sudah cukup banyak terjadi aksi teror di Australia yang dilakukan oleh orang-orang yang berasal dari Suriah (Mardiastuti, 2018). Australia memiliki pemikiran bahwa bisa saja kelompok teror Suriah melalui jaringan teknologi canggih memberikan perintah terhadap komplotan yang berada di Sydney untuk melakukan aksi teror yang lebih banyak lagi (Mardiastuti, 2018).

Selain itu, bentuk ancaman yang diberikan tidak hanya seputar itu melainkan juga ancaman dari adanya kerja sama yang dilakukan oleh para kelompok teror yang ada di berbagai negara, seperti Indonesia, Malaysia, Filipina, Australia, dan beberapa negara yang ada di Timur Tengah (Deutsche Welle, 2016). Bentuk kerja sama yang mereka lakukan adalah melalui pemberian aliran dana satu sama lain antarkelompok aksi teror yang ada di berbagai negara. Dengan adanya hal ini, ancaman terorisme dianggap semakin berbahaya dan akan bisa merebak luas di berbagai negara, khususnya di kawasan Asia Tenggara.

Negara-negara di kawasan Asia Tenggara mulai menerapkan berbagai kebijakan yang dianggap bisa memberantas atau mengantisipasi isu terorisme. Hal ini juga dilakukan oleh pemerintah Australia untuk menghadapi aksi-aksi terorisme yang terjadi (Kearens, 2012). Selain itu, Australia juga berupaya untuk menjalin kerja sama dengan Indonesia setelah peristiwa terjadinya Bom Bali 1 yang banyak melibatkan warga Australia. Berawal dari kerja sama tersebut, kerja sama dalam menghadapi terorisme antara Indonesia dan Australia semakin ditingkatkan dengan menjalin kerja sama bersama dengan ASEAN (Ansari, 2016).
Kerja sama Australia dengan Indonesia ini sebagai awal dari dimulainya kerja sama Australia dengan ASEAN, sebab negara yang mempelopori untuk menanggulangi permasalahan terorisme adalah Indonesia. Indonesia menjadi pelopor dalam aksi melawan terorisme karena di Indonesia banyak sekali aksi-aksi teror yang terjadi (Ansari, 2016). Hal ini dibuktikan dengan adanya peristiwa Bom Bali I dan II, kemudian peristiwa pengeboman di depan rumah Duta Besar Filipina di Indonesia, bom malam Natal di beberapa wilayah di Indonesia (Jakarta, Bandung, Mojokerto, Batam, Pekan Baru), serta bom bunuh diri yang terjadi di Hotel JW Marriot Jakarta (Irawan, 2018).

Peristiwa-peristiwa ini tidak hanya terjadi di Indonesia melainkan juga di negara-negara anggota ASEAN yang lain seperti di Filipina. Di Filipina sempat terjadi peristiwa pengeboman di Kota Davao, Selatan Filipina yang menewaskan 14 orang (Pars Today, 2018). Dari adanya peristiwa tersebut terdapat salah seorang yang mengatakan bahwasannya kelompok teroris Abu Sayyaf mengaku bertanggung jawab atas serangan bom di Davao. Peristiwa terorisme ini juga sempat terjadi di negara negara lain di ASEAN seperti Malaysia, Singapura, Brunei Darrusalam, dan Thailand (Nugroho, 2018).

Adanya berbagai peristiwa teror yang terjadi di negara-negara ASEAN belakangan ini membuat Australia semakin khawatir. Hal itu masih ditambah dengan munculnya kelompok teror Daesh yang berasal dari Irak dan Suriah yang akan menjadikan Asia Tenggara sebagai target selanjutnya (IKAHAN, 2018). Hal ini yang kemudian membuat Australia berkeinginan melakukan kerja sama dengan ASEAN dalam menghadapi terorisme di kawasan regional, karena kelompok Daesh ini merupakan salah satu kelompok teror cabang dari $\mathrm{Al}$ Qaeda yang saat ini sedang merebak di Australia dan akan menuju ke kawasan Asia Tenggara (Sekretariat Nasional ASEANIndonesia, 2019). 
Oleh sebab itu, penting bagi negaranegara ASEAN untuk menghadapi bentuk dari ancaman terorisme yang terjadi saat ini. Pemberantasan terorisme ini tidak akan bisa dilakukan hanya oleh satu negara saja. Sebab, aksi maupun tindakan terorisme ini tidak hanya terjadi di satu negara (Wati, Effendi, \& Edorita, 2015). Maka dari itu, muncul inisiatif dari negara-negara anggota ASEAN untuk menjalin kerja sama dalam menghadapi aksi -aksi terorisme yang marak terjadi. Hal ini diikuti oleh Australia karena Australia memiliki kekhawatiran bahwa para kelompok-kelompok terorisme mulai bergerak ke arah Asia Tenggara (Christiastuti, 2018). Australia merasa perlu untuk mengadakan suatu kerja sama melawan aksi terorisme karena Australia juga menyadari bahwa para kelompokkelompok terorisme ini tidak bisa dihadapi sendiri. Kesamaan perspektif terhadap ancaman terorisme di kawasan membuat ASEAN dan Australia pada akhirnya berupaya untuk menjalin kerja sama keamanan internasional dalam menghadapi terorisme.

Kerja sama keamanan ini penting bagi kedua mitra yang sedang menjalin kerja sama seperti ASEAN dan Australia untuk bisa mencapai kepentingan masing-masing negara. Dengan kerja sama dalam melawan terorisme, Australia berharap keamanan nasional dan perdamaian di negaranya akan bisa lebih terjaga (Permana, 2018). Dalam hal ini, Australia percaya terhadap ASEAN karena pemimpin negara- negara anggota ASEAN sepakat untuk melawan maupun memberantas kejahatan transnasional yang mana tindak kejahatan ini sangat berbahaya begi keamanan kawasan regional mereka. Selain itu, ASEAN juga menyetujui untuk menolak dengan keras masuknya Daesh ke negara mereka (Permana, 2018). Hal ini membuat Australia meyakini secara penuh dan kemudian menyepakati Teken MoU pada pertemuan KTT Istimewa ASEANAustralia di International Convention Centre Sydney, Australia (Mardiastuti, 2018).
Berdasarkan konsep kerja sama keamanan yang dipaparkan sebelumnya, kerja sama keamanan ini dikategorikan dalam keamanan dibentuk berdasarkan dari masalah domestis, sesuai dengan poin pertama menurut Perwita \& Yani (2005), yakni ketika berbagai ancaman yang dapat membahayakan negara berasal dari dalam atau domestik. Isu terorisme baik di Indonesia, Filipina, dan negara lain adalah berdasar dari aksi ekstrimisme agama, khususnya Islam. Permasalahan ini membuat isu negatif soal pandangan seseorang terhadap Islam. Masyarakat akan selalu memandang Islam sebagai agama yang buruk atau agama para teroris. Hal- hal ini menurut penulis menjadi salah satu faktor menurunnya keamanan negara, sehingga untuk menangani permasalahan seperti ini perlu tindakan serius dari pemerintah masing-masing negara tersebut agar tidak semakin luas dan bersifat lintas batas negara.

Selain itu, motivasi dari kerja sama yang dilakukan oleh ASEAN dan Australia ini adalah untuk menghadapi ancaman yang muncul dari luar. Ancaman ini kemudian memberikan dampak negatif bagi negaranegara yang mendapatkan ancaman, seperti halnya ancaman teror dari kelompokkelompok terorisme yang tersebar di seluruh negara-negara anggota ASEAN dan Australia. Motivasi kerja sama ASEAN tidak hanya seputar itu melainkan juga mengenai pemenuhan kepentingan nasional yakni menjaga keamanan negara-negara anggota kawasan Asia Tenggara dari ancaman terorisme dan berupaya untuk menjaga perdamaian antarnegara anggota ASEAN. ASEAN memiliki motivasi untuk menjaga perdamaian antarnegara anggotanya karena dalam isu terorisme ini hampir seluruh negara anggota ASEAN memiliki kelompok teroris serta di setiap negara terdapat kelompok jaringan pengucuran dana untuk aksi teroris (Deutsche Welle, 2016). Kerja sama itu dilakukan untuk menghindari adanya konflik agar negara-negara anggota ASEAN tidak saling menyalahkan atas 
permasalahan tersebut, sehingga tujuan akhir dari ASEAN yang berdasarkan dari prinsip APSC mewujudkan perdamaian akan tercapai.

Sedangkan motivasi Australia sendiri dalam menjalin kerja sama dengan ASEAN juga tidak sebatas permasalahan dalam menghadapi isu terorisme melainkan juga untuk memenuhi kepentingan nasionalnya dalam hal menjaga keamanan nasional. Australia belakangan ini sedang mengalami ancaman teror yang cukup besar, sehingga Australia merasa terancam akan keamanan nasionalnya. Maka dari itu, karena Australia secara sadar tidak akan mampu menghadapi ancaman terorisme secara mandiri, Australia menjalin kerja sama dengan ASEAN. Australia memilih ASEAN karena Australia mengetahui bahwasannya ASEAN merupakan target baru dari para pelaku terror. Selain itu, ASEAN juga menjadi sebuah organisasi regional yang mana negara-negara anggotanya menyetujui untuk melakukan perlawanan terhadap terorisme (Permana, 2018). Motivasi yang dimiliki oleh ASEAN maupun Australia menjadi dasar dari pembentukan kerja sama dalam menghadapi isu terorisme.

Selain itu, apabila ditinjau dari dimensi keamanan menurut Perwita dan Yani (2005), kerja sama keamanan yang dilakukan oleh ASEAN dan Australia ini masuk ke dalam kategori dimensi changing respons, yang mana cara-cara yang digunakan untuk menghadapi tindak kejahatan seperti terorisme tidak lagi mengedepankan tindakan militerisme, tetapi melalui aspek lain, seperti melalui teknologi siber, implementsi undangundang penanggulangan terorisme, pertukaran intelegen analisis keuangan multilateral ASEAN-Australia, serta penghentian aliran dana teroris Australia ke negara-negara anggota ASEAN (Permana, 2018; Suastha, 2018).

Kerja sama keamanan yang dibangun oleh ASEAN dan Australia dikategorikan dalam dimensi changing respons karena melihat kondisi perkembangan saat ini ketika peranan teknologi semakin besar, dan para kelompok teroris juga semakin gencar melakukan aksinya melalui tekonlogi. Untuk mengatasi hal itu, cara yang ditempuh juga harus melalui dimensi-dimensi soft power. Di samping itu, deteksi isu terorisme sangat sulit apabila diatasi dengan aksi militer.

Maka dari itu Australia berupaya untuk bisa bekerja sama dengan negara-negara anggota ASEAN dalam menghadapi ancaman terorisme. Sebelumnya, pada tahun 2000-an, Australia telah meminta bantuan Indonesia untuk bersama-sama menghadapi para teroris agar keamanan Australia bisa semakin terjaga. Kerja sama ini semakin diperluas oleh Australia bersama dengan negara anggota ASEAN yang lain agar Australia semakin mudah untuk bisa menjaga stabilitas keamanan wilayah domestik dan kawasan regional Asia Tenggara.

\section{KESIMPULAN}

Banyaknya peristiwa-peristiwa teror yang terjadi di kawasan Asia Tenggara membuat negara-negara anggota ASEAN melakukan kerja sama untuk menghadapi permasalahan terorisme. Akan tetapi, permasalahan ini tidak hanya terjadi di Asia Tenggara, tetapi juga di Australia. Belakangan ini, sering terjadi tindakan teror di Australia seperti penyanderaan pejalan kaki, bom bunuh diri, hingga penusukan oleh pejalan kaki yang dilakukan oleh seorang yang dianggap juga sebagai teroris. Hal ini kemudian membuat Australia memiliki inisiatif untuk menjalin kerja sama dengan ASEAN. Australia khawatir bahwa tindakan atau aksi terorisme yang berada di Asia Tenggara mulai menuju wilayah domestik Australia. Australia ingin melakukan kerja sama dengan ASEAN karena memiliki motivasi tersendiri, yakni untuk memenuhi kepentingan nasional negaranya yaitu menjaga keamanan nasional Australia dari berbagai ancaman terorisme, baik dari dalam maupun dari luar. Australia melakukan kerja sama karena pemimpin dari negara anggota ASEAN yang mayoritas 
Muslim menyetujui adanya pemberantasan aksi terorisme dan menolak dengan keras adanya kelompok Daesh yang masuk ke kawasan Asia Tenggara, yang mana kelompok tersebut telah memberikan ancaman terhadap Australia.

Sedangkan dari ASEAN sendiri, mereka memiliki motivasi dalam menjalin kerja sama dengan Australia yaitu agar Australia berkenan untuk memberikan bantuan dengan pemberhentian fasilitas pendanaan terhadap para pelaku teror yang ada di negara-negara anggota kawasan Asia Tenggara. Selain itu, ASEAN juga memiliki motivasi untuk bisa menjaga keamanan dan perdamaian kawasan dari segala bentuk ancaman yang terjadi. Maka dari itu, Australia dan ASEAN menjalin kerja sama dalam menghadapi terorisme ini untuk menjaga keamanan kawasan regional

\section{DAFTAR PUSTAKA}

\section{Buku dan Jurnal}

Ansari, R. (2016). Kerja Sama Bilateral Indonesia dan Australia dalam Penanganan Terorisme di Indonesia Tahun 2002-2013. Journal of International Relations, 2(1), 88-96.

Hartanto, W. (2016). Analisis Pencegahan Tindak Pendanaan Teroris Pada Era Masyarakat Ekonomi ASEAN. Jurnal Legislasi Indonesia, 13(4), 379-391.

Heywood, A. (2017). Politik Global (Edisi Kedua). Yogyakarta: Pustaka Belajar. Jackson, R. \& Sorensen, G. (2009). Pengantar Studi Hubungan Internasional. Yogyakarta: Pustaka Belajar.

Perwita, A. A, B. \& Yani, Y. M. (2005). Pengantar Ilmu Hubungan Internasional. Bandung: PT Remaja Rosdakarya.

Simanjuntak, S. Y., Utomo, T. C., \& Basith Dir, A. A. (2016). Analisis Kerja Sama Bilateral Indonesia Dengan Australia Dalam Penanggulangan Terorisme Sebagai Tindak Kejahatan Transnasional Terorganisir (2002- maupun keamanan nasional masing-masing negara, serta untuk meningkatkan kerja sama yang sudah dijalin sejak lama antara ASEAN dan Australia di bidang-bidang lain.

Adapun upaya eksternalitas yang dilakukan baik oleh ASEAN maupun Australia juga masih dirasa belum bisa melawan isu terorisme yang terjadi. Dari sini dapat disimpulkan bahwa kerja sama baik secara bilateral maupun multilateral dalam menangani isu terorisme sangat penting, serta berbagai motivasi yang ada untuk menjalin kerja sama ini juga bisa digunakan sebagai semangat oleh ASEAN maupun Australia dalam memanfaatkan peluang dari tantangan yang ada yakni isu terorisme. Kerja sama yang dijalin oleh keduanya nantinya diharapkan dapat semakin meningkatkan keamanan keduanya baik ASEAN maupun Australia.

2015). Journal of International Relations, 2(3), 117-127.

Suwardi, S. S. (2002). Peristiwa 11 September 2001 dan Penyerangan Amerika Serikat di Afghanistan Ditinjau dari Segi Hukum Internasional. Jurnal Hukum dan Pembangunan, No.1 Tahun XXXII, 724.

Wati, D. D. S., Effendi, E., \& Edorita, W. (2015). Peran ASEAN dalam Memberantas Tindak Pidana Terorisme Di Kawasan Asia Tenggara Berdasarkan Convention On Counter Terrorism. Journal Online Mahasiswa Fakultas Hukum, 2(1), 1-11.

\section{Skripsi, Tesis, dan Disertasi}

Kearens, H. (2012). "Kebijakan Luar Negeri Australia Terhadap Indonesia: Kebijakan Kontra-Terorisme Pasca Perang Bom Bali 1 (2002 - 2008)." Tesis. Jakarta: Universitas Indonesia.

Maulidy, A. I. 2011. "Kerja Sama Keamanan Indonesia, Malaysia, Singapura dalam Mengatasi Masalah Pembajakan di Perairan Selat Malaka 2004-2009." Skripsi. Jakarta: Jurusan Hubungan 
Internasional, Universitas Islam Negeri Syarif Hidayatullah Jakarta

Rizka, R. (2016). "Kerja Sama Kontra Terorisme Jepang-ASEAN dalam Upaya Menanggulangi Terorisme di Asia Tenggara." Skripsi. Makassar: Universitas Hasanuddin.

\section{Internet}

ASEAN. (2018). "ASEAN Poilitical Security Community Blueprint, ASEAN Foundation." Diakses dari https://asean.org/wpcontent/uploads/archive/518718.pdf.

Australia Government. (2015). "Australia's Counter-Terrorism Laws." AttorneyGeneral's Department. Diakses dari www.nationalsecurity.gov.au.

BBC. (2014) "PM Australia: Ancaman Terorisme Tetap Tinggi, BBC News Indonesia." Diakses dari https://www.bbc.com/indonesia/du nia/2014/12/141223_dunia_abbott_ terorisme.

BBC. (2016). "UNHCR: Kebijakan Australia Soal Pengungsi Tidak Bisa Diterima." Diakses dari https://www.bbc.com/indonesia/du nia/2016/03/160323_dunia_pengun gsi_indonesia.

Chandran, N. (2018). "The Terror Groups on Southeast Asia's Doorstep." CNBC. Diakses dari https://www.cnbc.com/2015/11/19 /paris-attacks-malaysian-killingputs-focus-on-southeast-asian-terrorgroups.html.

Christiastuti, N. (2018). "Australia Minta ASEAN untuk Waspada Terhadap Ancaman Teror Teknologi Tinggi." Detik News. Diakses dari https://news.detik.com/internasiona l/3921321/australia-minta-aseanwaspada-ancaman-teror-teknologitinggi.

Deutsche Welle. (2018). “Australia Terbanyak Pasok Dana Terorisme di Indonesia." Diakses dari https://www.dw.com/id/australiaterbanyak-pasok-dana-terorisme-diindonesia/a-19538757.

IKAHAN. (2018). "Forum Menhan ASEAN Australia Bahas Proyeksi Tantangan Keamanan dan Pertahanan." Diakses dari http://ikahan.com/2018/03/forummenhan-asean-australia-bahasproyeksi-tantangan-keamanan-danpertahanan/.

Irawan, I. A. (2018). "Pergeseran Orientasi Terorisme di Indonesia Tahun 20002018." Kumparan. Diakses dari https://kumparan.com/erucakragaruda-nusantara/pergeseranorientasi-terorisme-di-indonesia2000-2018.

Mardiastuti, A. (2018). "ASEAN-Australia Teken MoU Penanggulangann Terorisme Siber." Detik News. Diakses dari https://news.detik.com/berita/3922 209/asean-australia-teken-moupenanggulangan-terorisme-siber.

Nugroho, B. P. (2018). "Lawan Terorisme, 6 Negara di ASEAN Bentuk Our Eyes."

Detik News. Diakses dari https://news.detik.com/berita/3832 594/lawan-terorisme-6-negara-diasean-bentuk-our-eyes.

Pars Today. (2016). "Presiden Filipina: Peledakan Bom di Davao City, Aksi Teror." Diakses dari http://parstoday.com/id/news/worl d-i19516presiden_filipina_peledakan_bom_di_ davao_city_aksi_teror.

Permana, E. (2018). "Australia, ASEAN Sepakat Kerja Sama Inteligen Berantas Terorisme." Anadolu Agency. Diakses dari https://www.aa.com.tr/id/dunia/aus tralia-asean-sepakat-kerja-samaintelijen-berantasterorisme/1092029.

Suastha, R. D. (2017). "Australia-ASEAN Kerja Sama Hentikan Aliran Dana Teroris." CNN Indonesia. Diakses dari 
https://www.cnnindonesia.com/inte rnasional/20171122193403-106-

257458/australia-asean-kerja-samahentikan-aliran-dana-teroris.

Sekretariat Nasional ASEAN-Indonesia.

(2019). "Kerja Sama Kemitraan

ASEAN.” Diakses dari http://setnasasean.id.
Tempo. (2015). "10 Organisasi Teroris

Paling Berbahaya di Dunia.” Diakses

dari

https://dunia.tempo.co/read/65146

9/10-organisasi-teroris-palingberbahaya-di-

dunia/full\&amp;view=ok. 